\title{
Dt 16,18-20:
}

\section{Segue o que é reto e viverás com justiça}

\author{
Dt 16,18-20: \\ Follow what is right and you will live with justice
}

\section{Leonardo Agostini Fernandes*}

\begin{abstract}
* Doutor em Teologia Bíblica (Pontifícia Universidade Gregoriana, Roma) e Mestre em Teologia (Pontifícia Universidade Católica do Rio de Janeiro).

Sacerdote da Arquidiocese de São Sebastião do Rio de Janeiro. Professor no Departamento de Teologia da Pontifícia Universidade Católica do Rio de Janeiro, Brasil. laf2007@puc-rio.br
\end{abstract}

Recebido em: 15/07/2020

Aprovado em: 19/05/2021

Licença Creative Commons CC BY 4.0 (C) (i)

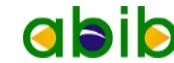

Associação Brasileira de Pesquisa Bíblica

\section{Resumo}

Um olhar atento para Dt 16,18-20 permite compreender bem uma das principais causas para o descuido com a vida humana e o descaso com o bem-comum, males que estão acontecendo em vários países. No lugar da soberania divina e da verdade revelada, o ser humano, vazio de fé e sem pensar nas consequências, tem se colocado como critério de justiça suprema e de verdade absoluta. Dessa atitude, surgem várias formas de injustiças que, associadas às constantes práticas de corrupção, estão abundando cada vez mais nas sociedades. Este artigo, após a introdução, centrada no ambiente histórico-literário, oferece uma tradução segmentada do texto em foco, uma proposta de organização, um breve comentário e é concluído com algumas considerações finais.

Palavras-chave: Livro de Deuteronômio, Dom do Senhor, Juízes, Justiça.

\begin{abstract}
A close look at Dt 16,18-20 allows us to understand one of the main causes for the carelessness with human life and the disregard for the common good, evils that are happening in several countries. In place of divine sovereignty and revealed truth, the human being, the faith emptiness and without thinking about the consequences, it has been put as a criterion of supreme justice and absolute truth. From this attitude, various forms of injustices, associated with the constant practices of corruption, are rising in societies. This article, after the introduction, centered on the historical-literary environment, offers a segmented translation of the text in focus, a proposal of organization, a brief comment and concluded with some final considerations.
\end{abstract}

Keywords: Book of Deuteronomy, Lord's gift, Judges, Justice. 


\section{Introdução}

No livro de Deuteronômio, Moisés possui um grande protagonismo. A maior parte do conteúdo do livro é veiculada em forma de discursos que o grande líder proferiu ao povo antes de morrer. Uma introdução (Dt 1,1-5), o relato das últimas ações (Dt 31,133,29 ) e o relato da morte de Moisés (Dt 34) emolduram esses discursos ${ }^{1}$.

No primeiro discurso (Dt 1,6-4,43), encontra-se uma recapitulação dos principais fatos que ocorreram desde a saída do Egito até a chegada nas terras de Moab. Esses fatos permitem um vislumbre sobre a terra de Canaã, finalizado com uma breve seção sobre as cidades-refúgio.

No segundo discurso (Dt 4,44-28,68), após uma breve introdução, a atenção do interlocutor é direcionada para uma longa legislação que inclui o Decálogo, o šema ', o conjunto de leis deuteronômicas, finalizando com bênçãos e maldições.

No terceiro discurso (Dt 28,69-30,20), o tema central é a renovação da aliança nas estepes de Moab. O tom é profético, pois Moisés oferece aos seus interlocutores um olhar para dois acontecimentos futuros: o exílio e o retorno à terra. Dt 30,11-14 é uma espécie de eixo central.

Do ponto de vista literário, o livro de Deuteronômio, por um lado, pode ser visto como se fosse um testamento, que Moisés, antes de morrer, deixou para o povo. Por outro lado, o livro relata o porquê se fez necessária a renovação da aliança, exigida pelo Senhor e selada nas estepes de Moab, com o "novo Israel", que nasceu e cresceu durante o período do deserto. Essa renovação deveu-se à ruptura da aliança, selada no Sinai, com os seus pais, isto é, os que foram libertos do Egito. Essa ruptura foi causada pela fundição e idolatria de um bezerro de ouro (Dt 9,7-10,11; paralelo a Ex 32).

Dentro dessa lógica, Dt 16,18-20 tem a ver com um importante fator que deve garantir a vida do povo e a sua existência na terra de Canaã: o cuidado com a prática da justiça e do direito. Apesar de ser uma seção que parece deslocada no contexto em que se encontra, tem a ver com o culto e a sua integridade, mas, em particular, com a estruturação social que está pautada em um regime teocrático, centrado nos envolvidos que assumem postos de comando (Dt 16,18-18,22)2: juízes (Dt 16,18-20) e

1 Sem adentrar na discussão acadêmica, mas seguindo a forma final e canônica do livro, as suas partes podem ser identificadas quer pela presença de um título (Dt 1,$1 ; 4,44 ; 28,69 ; 33,1$ ), quer pela dinâmica do conteúdo (PAPOLA, 2011, p. 17). Há, porém, quem subdivida o livro em três partes, mas considere apenas dois discursos de Moisés, motivado, principalmente, pela forma final do livro de Deuteronômio e da Torá (PAGANINI, 2011): abertura (Dt 1,1-5); primeiro discurso (Dt 1,6-4,43); segundo discurso (Dt 4,44-26,19); conclusão (Dt 27,1-34,12).

2 Essa seção, que trata de diferentes formas de autoridade constituída, em particular voltada para o futuro rei (BARRETT, 2009), pode ser considerada central dentro do "Código Deuteronômico" (Dt 12-26*), e tem a ver com a ordem de honrar pai e mãe, a fim de que se tenha uma longa vida sobre a terra de Canaã (Dt 5,16). Enquanto o Senhor é a fonte da legislação, os genitores são considerados as testemunhas dessa fonte (PAPOLA, 2011). 
administradores processuais (Dt 16,21-17,13); o rei (Dt 17,14-20); os sacerdotes e os levitas (Dt 18,1-8); o verdadeiro profeta (Dt 18,9-22) ${ }^{3}$.

Moisés reuniu, na sua pessoa, essas características, pois, filho de levitas (Ex 2,1; 6,20), foi libertador do Egito, guia na marcha pelo deserto rumo à terra de Canaã, legislador, juiz, responsável pelo "nascimento do povo" eleito, consagrado ao Senhor, e líder mediador da aliança que selou a eleição e transformou os libertos em um povo politicamente organizado.

O livro de Deuteronômio, porém, representa apenas o término do período que lançou as bases da história social e religiosa desse povo. A sua importância teológica tem a ver com a sua natureza: é o terminus ad quem da Torá. "O Deuteronômio, de fato, relê o complexo da Torá dizendo dela, contemporaneamente, a sua realização" (PAPOLA, 2011, p. 21).

Sobre essa realização, Dt 16,18-20 joga um singular papel, pois o olhar contempla como cada cidade deveria ser organizada juridicamente e como a Torá devia ser cumprida em função do bem-comum. Em três versículos se condensa o que se espera que aconteça na terra de Canaã: que o conhecimento da Torá determine o comportamento do povo e que este esteja estabelecido com base na prática da justiça e do direito, condição indispensável para cuidar e zelar pela vida. De maneira analítica e por meio de uma abordagem sincrônica, busca-se individuar os principais aspectos literários, semânticos e teológicos presentes em Dt 16,18-20.

\title{
2 Segmentação e organização do texto ${ }^{4}$
}

\author{
v. 18a: Juízes e oficiais colocarás para ti em cada uma de tuas portas \\ v. 18b: que o SENHOR, teu Deus, dá para ti segundo as tuas tribos. \\ v. 18c: Julgarão o povo com reta justiça. \\ v. 19a: Não desviarás a justiça; \\ v. 19b: não distinguirás pelas faces; \\ v. 19c: não pegarás um dom, \\ v. 19d: porque o dom cega os olhos do sábio \\ v. 19e: e perverte as palavras dos justos. \\ v. 20a: Persegue o que de fato é reto, \\ v. 20b: para que vivas \\ v. 20c: e possuas a terra \\ v. 20d: que te dá o SENHOR, teu Deus.
}

3 Dt 16,18-18,22 se ocupa do tríplice múnus sobre o qual se apoia esse regime: régio, sacerdotal e profético, mas se nota que as autoridades coletivas precedem as individuais (PAGANINI, 2011).

4 Tradução própria a partir da Bíblia Hebraica Quinta (quinta editione cum apparatu critico novis curis elaborato), אלה הדברים-Deuteronomy (MCCARTHY, 2007). 
A locução: "Senhor, teu Deus", e o verbo "dar", presentes no v. $18 \mathrm{~b}$ e no v. $20 \mathrm{~d}$ determinam o sentido da seção e das ações nela contidas. A seção, então, pode ser subdividida em doze segmentos e gira em torno de dois elementos positivos (v. 18a.c) e três proibições (v. 19abc), que, por sua vez, são vistos como a origem de desvios (v. 19de). Em contrapartida, o sentido para estabelecer "juízes e oficiais" (v. 18a), está em função da ação adequada: "persegue o que é reto" (v. 20a), que tem uma dupla consequência: "para que vivas e possuas a terra" (v. 20bc).

O "novo Israel" é, dessa forma, prevenido contra o que atestaria a sua insensatez: burlar a justiça e perverter o direito. Pode-se perceber que a experiência da opressão e das injustiças vividas no Egito não devem manchar a identidade e a conduta do povo na terra de Canaã. A prática da justiça e do direito deve ser o seu maior diferencial, porque o Senhor Deus é justo.

Caso isso não aconteça, o "novo Israel" não seria considerado um povo sábio aos olhos dos demais povos e iria na contramão de Dt 4,8: "E que grande nação tem leis e normas tão justas como é toda esta legislação que, hoje, eu vos exponho?" A característica singular dessa seção, segundo a lógica da narrativa situada no período do deserto, é lançar um olhar para o futuro e sublinhar, em tom exortativo, o tema da imparcialidade na aplicação da justiça que se apoia sobre a ação do Senhor que, também, age com imparcialidade (PAPOLA, 2011).

\section{Breve comentário}

\section{1 "Juízes e oficiais colocarás para ti em cada uma de tuas por- tas" (v. 18a)}

A experiência do êxodo e da marcha pelo deserto havia permitido que o povo passasse para uma nova condição de vida: da escravidão para a liberdade; razão pela qual as relações também passaram a demandar a necessidade da descentralização do poder que estava sob os ombros do líder Moisés ${ }^{5}$. Nesse sentido, Dt 16,18-18,22 condensa as principais formas de liderança que servem para orientar e guiar o povo na execução obediente da vontade de Deus.

5 O mesmo episódio conheceu várias tradições e, por isso, se encontram presentes três versões na Torá. Na primeira (Ex 18,13-27), a descentralização do poder aparece sugerida pelo sogro de Moisés. Na segunda (Nm 11,14-30), ela deriva de uma queixa de Moisés e de uma ordem divina. Na terceira (Dt 1,9-18), é fruto de uma percepção imediata do próprio líder. $2 \mathrm{Cr} 19,5$-11 é um texto próximo a Dt 16,18 -20 ou a Dt 17,8-13. "Uma organização judicial, com funções distribuídas em tribunais menores, deve ter surgido e ter sido estabelecida, com maior probabilidade, durante o período da monarquia" (FERNANDES; GRENZER, 2011, p. 156). 
A ordem para estabelecer "juízes"6 e "oficiais", além de continuar a dinâmica libertadora da experiência exodal, atestava uma continuidade tática a ser cumprida nas cidades que fossem ocupadas por cada uma das doze tribos. Caberia, então, aos seus anciãos, que pertenciam às famílias patriarcais, enquanto sujeitos idôneos e líderes de grupo, significados na segunda pessoa do singular (WRIGHT, 2009), a tarefa e a responsabilidade de constituir juízes e magistrados, pois Moisés não mais estaria na liderança delas (PAGANINI, 2011).

A menção das portas refere-se à prática do estabelecimento dos tribunais que não apenas julgavam os casos ocorridos dentro da cidade, mas também tinha a ver com a permissão ou a proibição do ingresso e da saída de cidadãos e de estrangeiros.

Deixar entrar, não deixar entrar ou colocar para fora de uma cidade são ações que representavam a dinâmica da justiça e do direito procurados e exercitados em função do cuidado com a vida de cada cidadão e do bem-comum que a torna possível. Esse triplo movimento, de forma metafórica, tem a ver com a ingestão de alimentos (deixar entrar), a sua rejeição (não deixar entrar), e com a necessidade de "vomitar" o que estivesse fazendo mal (colocar para fora). Nesse sentido, a porta de uma cidade está em relação à boca de quem recebeu o encargo de emitir o justo juízo sobre uma pessoa a partir da sua ação, reação ou omissão em relação aos demais cidadãos que nela viviam.

A porta, ou o portão, de uma cidade deveria ser resistente e forte; capaz de oferecer a segurança necessária para quem nela habitasse. Em geral, dava acesso,

6 O particípio hebraico: "os que julgam”, daí "juízes”, deriva do verbo šāpat ("julgar, salvar, livrar, governar") e o seu uso, pelo contexto, tem a ver com uma pessoa que é colocada entre outras duas que não conseguem resolver, por si mesmas, um litígio ou conflito. Em Gn 16,5, Sara, em contenda com Abraão, invoca o Senhor como juiz de sua causa, visto que a matéria estava acima da competência humana, mas também porque Abraão, na qualidade de líder do seu grupo, estava envolvido na questão e não podia servir de juiz, pois correria o risco de não ser imparcial no julgamento. O mesmo particípio foi usado como designação do sétimo livro bíblico, no qual os "juízes maiores" agiram como líderes libertadores pela ação militar; já os "juízes menores" agiram como administradores da justiça e do direito, a fim de manter a paz no meio do povo (CULVER, 1998).

7 O substantivo hebraico šottēer designa um funcionário que executa ordens. Faz sentido, então, que venham citados depois dos juízes aos quais deviam ser subalternos, e estavam encarregados de atuar em diferentes frentes na sociedade. Nm 11,16 os subordina aos anciãos que foram escolhidos para ajudar Moisés na administração da justiça e do direito (Dt 1,15). Com a queda do regime monárquico, esses "oficiais" aparecem envolvidos em assuntos militares e cultuais ( $1 \mathrm{Cr} 27,1 ; 2 \mathrm{Cr} 19,11)$. Pela função judicial e religiosa, que desempenhavam, eram, possivelmente, treinados "no ofício e na arte dos escribas" (PATTERSON, 1998, p.1550-1551).

8 Apesar de não se encontrar na obra deuteronomista de história, talvez essa legislação seja uma alusão ao rei Josafá que empreendeu reformas no âmbito da justiça e do direito, pois criou, além dos tribunais locais, uma jurisdição central em Jerusalém confiada a sacerdotes, levitas e anciãos (2Cro 19,4-11). Com isso, aliviou o seu peso de "suprema corte e última apelação" (LORENZIN, 2011, p. 310-311; BALZARETTI, 2013, p. 302). 
primeiramente, a uma praça que servia para a reunião dos habitantes por ocasião de pronunciamentos públicos, relativos às questões sociais, administrativas e comerciais.

Além disso, existiam espaços destinados aos soldados, para que pudessem atuar em algum caso de ataque; mas junto à porta, ou ao portão, se sentavam os anciãos, membros que formavam o conselho local, isto é, o tribunal (Dt 25,7; Rt 4,1-12). Eram homens considerados de valor e muito respeitados em sua reputação, tanto pessoal como familiar, em particular coadjuvados pelas mulheres que não podiam difamar a imagem louvável dos seus esposos, mas deviam lhes acrescentar respeito frente aos cidadãos $(\operatorname{Pr} 31,11.23)^{9}$.

A cidade, que pudesse contar com "juízes e oficiais", era considerada importante, pois estava munida de representantes legais para resolver as suas questões. Por isso, não precisaria recorrer a outra cidade ou buscar uma instância superior. A cidade, por seu juiz, demonstrava, então, a sua autonomia e a capacidade de cuidar e de gerir as relações dos próprios cidadãos ${ }^{10}$.

\section{2 "que o SENHOR, teu Deus, dá para ti segundo as tuas tribos" (v. 18b)}

O dom ao qual Moisés se refere são as cidades, pois é a ideia que subjaz à locução: "tuas portas". É um passo importante na trajetória do povo que, pela lógica da narrativa, estava prestes a deixar de ser nômade para se tornar cidadão. E mais do que isso, porque, segundo o livro de Deuteronômio, o povo tomaria posse de cidades que não teve, sequer, o trabalho de construir (Dt 6,10; Js 24,13).

Essa mudança de status, por certo, traria benefícios, mas, também, novos desafios, pois viver em uma cidade não era o mesmo que viver no deserto sob a liderança de Moisés. Assim, o estabelecimento de "juízes e oficiais" tinha uma dupla valência. Por um lado, lembravam a singularidade presente na figura do grande líder, pelo qual o Senhor havia dado as suas leis e falado face-a-face (Dt 34,10). Por outro lado, seriam os responsáveis por orientar, conduzir e regulamentar a vida do povo de acordo com as leis, normas e estatutos contidos na Torá. Isto tinha por objetivo: cumprir a vontade do Senhor; assim, a vida do povo estaria assegurada.

Não se pode esquecer que, antes da dádiva das cidades, o povo, segundo a narrativa, recebeu o dom da Torá e que a aliança, estabelecida no Sinai, visava garantir

9 Há quem tenha proposto que o sintagma: tuas portas no livro de Deuteronômio, não indique algo físico, mas seja uma alusão aos acordos que se estabeleciam entre as partes litigantes (FRESE, 2015). Uma cidade, dependendo do seu tamanho, podia ter várias portas (AUSTEL, 1998). Subjaz a essa concepção a promessa que Jesus fez aos seus apóstolos de que se tornariam juízes (Mt 19,28; Lc 22,28-30).

10 Para o livro de Deuteronômio, fazer justiça ao pobre é um direito inalienável (BRUEGGMANN, 2001). Lc 18,1-8 atesta que sem o temor de Deus nenhum juiz terá respeito pelo ser humano e suas necessidades. É um contrassenso, portanto, que um juiz seja declarado antídikos, isto é, que se opõe à justiça. Em contrapartida, a arma da viúva, desprovida de bens e fustigada pelo seu inimigo, é sua dignidade e sua audácia em enfrentar o juiz e exigir que lhe seja feita justiça (CRIMELLA, 2015). 
a vida do povo nas mãos de quem o tirou da terra do Egito e do meio da opressão. É fundamental perceber a íntima relação que existe entre quem dá, o que está sendo dado e para quem está sendo dado.

Assim, já desponta, na relação entre os dois segmentos do v. 18, a noção e a insistência na igualdade. Não obstante o número de membros das doze tribos ${ }^{11}$ fosse desigual, como aparece no relado da contagem do "novo Israel", nascido no deserto e que adentraria na terra de Canaã (Nm 26), a disposição jurídica deveria ser a mesma e proporcional às necessidades.

O dado singular reside na ação: "dar", e que depende do mesmo sujeito: o Senhor (como no v. 20d). Por este prisma, o "novo Israel" deveria tomar consciência de que um futuro promissor adviria como resultado desse dom que, como um verdadeiro šălôm, precisava ser protegido e garantido pela administração da justiça e do direito em todos os níveis sociais ${ }^{12}$.

A ação favorável do Senhor tem um objeto preciso: "dar para ti”, e se destaca como uma marca característica do livro de Deuteronômio, pois ocorre cerca de cinquenta e cinco vezes e, em todas, o Senhor é sempre o sujeito da ação. Nesse sentido, ao povo compete se espelhar nas ações do seu Senhor. Fica clara a indicação da origem, por exemplo, das principais dádivas que foram concedidas ao povo: a lei e os juízes, a terra fértil e seus frutos, o culto e o seu local escolhido. Por esses dons, pode-se entrever a base para o tríplice múnus do messias: régio, por ser administrador da justiça e do direito; profético, por falar em nome do Senhor; e sacerdotal, por ser o edificador do santuário e o seu principal guardião-representante ${ }^{13}$.

\section{3 "Julgarão o povo com reta justiça" (v. 18c)}

A ação de julgar, pelo contexto, fica restrita aos "juízes", mas, provavelmente, caberia aos "oficiais" o registro e a execução do que ficasse determinado no julgamento. Deve-se perceber que essa função, na verdade, é uma participação na ação do próprio Senhor que concede o dom, pois é o justo juiz de todas as causas e que julga por excelência e imparcialidade.

11 O sistema tribal de governo, indicado pelo substantivo šêbet e que se traduz por "bastão, cajado, cetro", como instrumento, por exemplo, necessário ao pastor para proteger, castigar ou disciplinar, perdurou até o advento da monarquia. A ligação entre še $\underline{b}$ et e tribo, sinônimo de matțeh, tem a ver com a expressão de domínio e de autoridade. As alusões em Gn 49,10.16.28 permitem compreender essa ligação (WALTKE, 1988).

12 A união estreita com o Senhor serve, antes de tudo, para demonstrar que a administração da justiça e do direito em Israel tem a ver com o regime teocrático, razão pela qual o empenho pelo cumprimento recebe uma maior consideração pela consequente submissão à vontade do Senhor, pois a legislação vivida de forma imanente tem origem transcendente (WRIGHT, 2009).

13 O Sl 110 atesta a tríplice relação: régia, profética e sacerdotal, que recai sobre a figura do messias, a fim de que cumpra, como filho, o seu papel de representante da divindade (FERNANDES, 2015). 
Os casos que ocorreram ao longo do tempo do deserto, por certo, serviram de exemplo, preparação e tirocínio para os que foram encarregados das funções jurídicas junto ao povo. Contudo, precisa ficar em evidência que as ações e as reações do Senhor, em relação ao povo e às suas murmurações, são o paradigma e a inspiração dos "juízes e oficiais". Como o Senhor foi imparcial e julgou com justiça, de igual modo os juízes deviam julgar (Dt 10,17).

A locução "reta justiça", ou justa sentença, combina dois substantivos fundamentais ${ }^{14}$ e só nessa passagem da Torá estão lado-a-lado. A compreensão e o alcance podem ser percebidos graças a outras alusões. Jó recorda que o Senhor não pode desviar os rumos da justiça ou subvertê-la (Jó 8,3). Por isso, a sentença deve ser feita com equi-

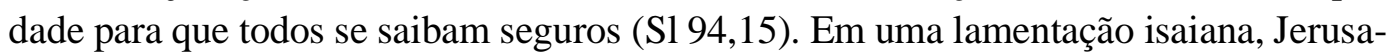
lém foi duramente criticada por ter abandonado a prática do direito e da justiça (Is 1,21). Um exemplo disso aparece quando o pobre foi vilipendiado (Am 2,6-16), ou se negou o justo salário ao trabalhador (Jr 22,13).

A esperança foi alimentada pela promessa de envio do messias descendente davídico que, repleto dos dons do Senhor (Is 11,1-10) ${ }^{15}$, seria um agente transformador tanto ad intra como ad extra da nação, solícito quanto ao direito e pronto para praticar a justiça (Is 16,5).

Para que o princípio da "reta justiça" fosse devidamente compreendido, foram então apresentadas, na sequência, três proibições que são próprias do direito não casuístico, como é o caso do Decálogo (Ex 20,1-21; Dt 5,1-22), mas que mostram a sua ligação com o regime tribal, pelo qual costumes se transformam em leis que, por sua vez, permitem ou pró́bem ações (direito consuetudinário).

14 Os substantivos mišpāt e ședeq são funcionais, muito frequentes em todo o AT, e vão entendidos de acordo com os diferentes âmbitos da vida pessoal, social e cultual, combinando a prática com a base sobre a qual o direito se desenvolve (PAGANINI, 2011). O primeiro, derivado da raiz špt, significa julgar, daí, geralmente, ser traduzido por "justiça", mas seu alcance e aplicação não se reduzem à esfera do direito, pois a principal intenção visa restabelecer a ordem nos seus diferentes níveis sociais (LIEDKE, 1978). O segundo, derivado da raiz șdq, possui uma conotação mais funcional no contexto da conduta adequada que se deve ter no âmbito da comunidade, sem que essa conduta se reduza, simplesmente, à esfera moral. Em geral, é traduzido por "direito", mas denota o equilíbrio e a equidade das relações humanas (KOCH, 1978).

$15 \mathrm{O}$ mišpāt expressa a esperança da ideologia régia, pois de um monarca se espera encontrar, mais que habilidade militar, a capacidade de ser justo e de gerir a justiça social. O ungido do Senhor, em Is 11,1-10, promoverá a justiça não pela guerra, mas pela força e persuasão da palavra, usada a favor da libertação do mais fraco (MELLO, 2012). Segundo Fernandes (2020, p. 37): "Is 11,1-3a contém uma terminologia próxima à fé jahwista, praticada em Judá-Jerusalém. Para a fé, é fundamental o conhecimento de YHWH que advém dos seus grandes feitos salvíficos, na vida e na história, a favor do seu povo. Mas, com o ungido, esse conhecimento deve determinar o comportamento de todo o povo, de acordo com a vontade de YHWH (Is 11,3b9). Retidão e justiça se tornam, então, consequências elementares na vida de quem conhece YHWH e o reconhece como único Deus, fazendo essa fé chegar aos outros povos e nações (Is 11,10)". 


\section{4 “Não desviarás a justiça” (v. 19a)}

A primeira proibição apresenta uma mudança significativa, pois o sujeito está no singular, podendo ser uma referência abrangente: o juiz estabelecido, mas também o povo ("para ti"), e possui um claro objeto: "a justiça" que, de fato, é uma responsabilidade comum (PAPOLA, 2011). A tradução do segmento também poderia ser: "não te desviarás da justiça" ou "não serás a causa do desvio da justiça". É ilícito usar a justiça com fins espúrios. Tal desvio não tem a ver, diretamente, com a possibilidade de se mudar a natureza da justiça, porque é ação de aprendizado divino, mas de pervertê-la e alterá-la em um tribunal.

Mas, em que sentido? Outros dois textos podem ajudar a compreender. No "Código da Aliança" (Ex 20,22-23,33), encontra-se a tentativa de impedir, ou pelo menos de frear, as tentativas de transgressão na administração da justiça ao se proibir que, em um processo, o direito do pobre fosse desviado (Ex 23,6). Tal pobre aparece definido em Dt 24,17 que, por sua vez, pró́be que se perverta a justiça devida ao estrangeiro e ao órfão, e impede, inclusive, que a veste da viúva seja tomada como penhor ${ }^{16}$.

A pena para esse tipo de crime já estava declarada em Ex 22,20-23 e relacionada com a lei do talião. Além do mais, tal crime é passivo inclusive de maldição (Dt 27,19). A base para essa proibição e sua aplicação ao pobre deve fazer o povo lembrar a dura condição em que viveu no Egito, como escravo (Dt 15,15), razão pela qual foi resgatado pelo Senhor, com mão forte e braço estendido (Ex 6,6; Dt 4,34; 5,15; 7,19; 11,2; 26,8). Esta ação do Senhor, pela qual libertou o seu povo, encontra-se subjacente ao sentido do que se proíbe fazer, pois, é pelo bem que se deve estender o braço e libertar o ser humano da opressão e não para retardá-la ${ }^{17}$.

\section{5 “não distinguirás pelas faces” (v. 19b)}

Não parece que essa segunda proibição, única em todo o Antigo Testamento, tenha a ver com a estética ou a beleza natural de uma pessoa, mas estaria em relação ao nível social ao qual a pessoa poderia pertencer. Contudo, os mais ricos, por terem melhores condições de vida, podiam proteger melhor a própria face com mantos, cremes e unguentos, enquanto os mais pobres apresentavam, na face, a dureza da vida e dos maus tratos. Em outras palavras: os cuidados com a própria face revelariam as posses das

16 Ex 22,25-26 e Dt 24,10-13 buscam salvaguardar o direito do pobre que se endividou. A proteção do pobre de qualquer forma de exploração econômica é uma característica do livro de Deuteronômio, pois, quem caiu na pobreza, precisa que a sua dignidade seja salvaguardada (WRIGHT, 2009). Para uma aproximação dos textos do livro de Deuteronômio e a mishná, sobre a defesa dos pobres, em particular do órfão, da viúva e do estrangeiro, veja-se o artigo, em duas partes, de Frizzo (2010a; 2010b).

17 A noção que subjaz ao verbo nătâ é que algo foi esticado, compreende-se que o desvio, ou a perversão, alude à transgressão, ou à enrolação, cometida na ação processual, a fim de que o pobre fosse negligenciado nos seus direitos e a sua vida ficasse declinada pela falta de lealdade ao que ela representa (WILSON, 1998). 
pessoas e a condição social à qual pertenciam, julgando pela aparência ${ }^{18}$ e não pelo confronto com a legislação vigente.

O Sl 82,2 fala do julgamento falso para sustentar a causa dos ímpios. A mesma ideia se encontra em Pr 18,5 ao falar da injustiça que se comete, em um julgamento, ao se favorecer o ímpio em detrimento da justiça a ser feita em favor do justo. Em um tribunal, a imparcialidade é, por certo, condição sine qua non para que injustiças não sejam praticadas $(\operatorname{Pr} 24,23 ; 28,21)$.

Assim, tal proibição aponta para a corrupção e o suborno aos quais um juiz poderia estar sujeito, ao olhar a face das partes litigantes ou ao perceber alguma simulação, fazendo, então, acepção de pessoas e procurando tirar vantagem da sua posição social diante de povo, em particular contra o mais fraco e necessitado.

Sem dúvida, a proibição busca inibir, inclusive, o enriquecimento às custas do suborno ou da troca de favores que comumente poderia ocorrer no interesse entre amigos. No fundo e no fim, a figura do juiz ficaria completamente desmoralizada e o povo perderia a esperança de que conseguiria a justiça capaz de restabelecer o adequado ordenamento das relações.

\section{6 “não pegarás um dom” (v. 19c)}

A terceira proibição é paralela a Ex 23,8a e apresenta o que corrompe o juiz e prejudica a aplicação da justiça: o presente que suborna. Ao invés da objetividade e da imparcialidade do juiz, a ação seria praticada com base nos agrados a ele enviados ou pagos às ocultas. São as propinas que tanto corroem as ações na sociedade e causam tantos males públicos.

O pobre, diante disso, não teria chance de obter justiça em um julgamento e este, por sua vez, nunca seria justo, a ponto de condenar o culpado e absolver o inocente. Não à toa que o grande líder Moisés nunca aparece envolvido em uma situação desse gênero. Ele é íntegro e permaneceu ilibado no seu ímpeto e ações, pois sempre julgou conforme a lei do Senhor. Nm 12,3 tece um grande elogio a Moisés e o define como o mais humilde dentre os homens. De fato, a virtude da humildade funciona como um antídoto contra a corrupção dos costumes.

Disto resulta que o ser humano íntegro, que pode comparecer diante do Senhor no santuário, é descrito como aquele que não empresta dinheiro a juros e não aceita suborno contra o inocente (S1 15,5). Isto, porém, não quer dizer que poderia aceitar contra o culpado. Em contrapartida, o ímpio aceita suborno às escondidas, tanto de testemunhas como dos imputados, para distorcer a justiça e o direito contra o justo (Pr 17,23).

18 A pluralidade de sentidos subjacentes ao verbo nākar não permite compreender, de imediato, o sentido ao qual o texto se refere. Subjaz um aspecto ou uma expressão facial que poderia, inclusive, significar um sinal de que algo poderá ser realizado. É a face do suborno! Por meio dessa ação dissimulada, o juiz daria uma interpretação equivocada, a fim de favorecer quem fez a simulação facial. É como se pusesse um disfarce sobre a lei, de modo a tornar a justiça irreconhecível. É a desfiguração da lei e a deturpação da justiça (WILSON, 1998). 
Is 1,23 retrata bem essa proibição e suas consequências: "Os teus líderes são rebeldes e cúmplices de ladrões; todos são ávidos de presentes, buscam propina, não fazem justiça ao órfão e a causa da viúva não os sensibiliza". Tal ato deturpa o bem. Por isso, são alvo dos juízos divinos, porque livram o ímpio por suborno, negando a justiça e o direito ao justo inocente (Is 5,23). Em contrapartida, louva-se quem pratica a justiça, fala o que é reto, despreza o suborno e não se envolve em crimes, ou de derramamento de sangue (Is 33,15; Ez 22,12). Para que tais coisas fossem evitadas, a ação se tornou matéria de maldição (Dt 27,25).

\section{7 "porque o dom cega os olhos do sábio" (v. 19d)}

Este segmento enfatiza o campo da visão. A conjunção, que abre a frase explicativa, mostra a razão suficiente para que o juiz, ou as testemunhas, se forem sábios, não aceitem algum tipo de presente tendencioso e que visa subornar. Ao aceitar, já se tornaram coniventes com a ação. A mesma razão já estava presente no "Código da Aliança” (Ex 23,8b) ${ }^{19}$, mas a referência ao sábio é um dado particular e exclusivo do v. 19d que se aproxima a Eclo 20,29a.

Uma vez que nenhum ser humano está imune da corrupção que, por sua vez, deriva da desobediência original, faz-se necessário seguir o paradigma de imparcialidade na aplicação da justiça: o Senhor (WRIGHT, 2009; PAGANINI, 2011). Assim, a orientação legal, recebida no deserto, segundo a narrativa, mostra, por um lado, que o motivo tem a ver com a liberalidade do Senhor (Dt 10,17); e, por outro lado, visava prevenir sobre o que se tornaria uma prática recorrente, em particular, entre os monarcas (1Rs 15,19; 2Rs 16,8).

Com isso, tal prática acabou por criar um neto contraste, pois de Ciro, porém, se diz que a sua ação seria isenta de indenização, isto é, seria gratuita (Is 45,13), aproximando-o ainda mais do próprio Senhor que o escolheu como seu ungido (Is 45,1).

Portanto, quem não consegue ver com clareza não pode emitir um juízo condizente com a realidade a ser julgada com base na justiça e no direito, isto é, condizente com a verdade.

\section{8 “e perverte as palavras dos justos" (v. 19e)}

Este seguimento é paralelo a Ex 23,8c e Eclo 20,29b tem uma sentença próxima, mas ao invés de distorcer ${ }^{20}$, o dom que suborna amordaça a boca do sábio, isto é,

19 O "Código de Hammurabi" (L 5) não admitia que um juiz mudasse de decisão, uma vez que a sentença tivesse sido sancionada, e punia com a expulsão do cargo o juiz que fizesse tal coisa (RICHARDSON, 2004).

20 A ação latente ao verbo sālap̣ tem a ver com a perversão que causa a desonestidade em campo social e moral, pois arruína não apenas com os bens de uma pessoa, mas também com a sua integridade. $\mathrm{O}$ dilema do justo é ver o malvado prosperar por sua deslealdade (Sl 73), mas a sabedoria mostra a contraposição e o valor do sábio em relação ao estulto, ímpio e desleal (PATTERSON, 1998). Na terra de Canaã, cuja 
impede de falar a verdade e que seja emitida a justa sentença. Aqui, a alusão aos "justos" pode ser uma referência tanto aos juízes como às testemunhas, mas abarca, igualmente, todo o povo. Já a locução, "palavras dos justos", poderia indicar uma relação de identificação (genitivo epexegético).

O juiz, para emitir a sua sentença, deve ouvir as partes em litígio e as testemunhas que são chamadas em causa. Dt 19,15 proíbe que alguém seja considerado culpado com base em uma única testemunha e estabelece que o depoimento advenha de no mínimo duas ou três testemunhas. Tal procedimento visava proteger a parte mais frágil e assegurar a objetividade e a veracidade dos fatos. 1Rs 21 mostra uma clara distorção dessa lei pela imposição do poder.

No fundo, quem se deixa subornar demonstra que não considera a retidão existente nas palavras do justo que comparece ao tribunal. É uma ação que viola o sistema que deveria ser coerente e capaz de controlar, com equilíbrio, as relações entre as partes em litígio, a fim de evidenciar a veracidade dos fatos e sua ligação com as palavras pronunciadas.

\section{9 "Persegue o que de fato é reto" (v. 20a)}

As três proibições são combatidas com uma única ordem que permite constatar, em primeiro lugar, que nenhum ser humano é virtuoso por natureza, mas deve ser orientado a se empenhar muito na busca e consecução da honestidade; em segundo lugar, atesta-se que é necessário o discernimento na hora de eleger e de perseguir "o que de fato é reto" (Lv 19,36).

A tradução, "o que de fato é reto", é uma tentativa de aproximação à forma como se encontra no original hebraico que concatena, por duas vezes, o mesmo substantivo: sedeq ședeq, isto é: "justo-justo", ou "reto-reto", ou ainda "justiça-justiça"21. Subjaz à formulação algo do gênero: "persegue o retamente reto"; "persegue o justamente justo"; "persegue a justa justiça".

Com isso, deixa evidente a relação que existe entre o objeto e o verbo, que indica a ação de "seguir algo", "ir atrás de algo ou de alguém", daí perseguir no sentido positivo da ação ${ }^{22}$. Quase que seria possível dizer: "fazer-se discípulo do que é justo" ou "de quem é justo". Por isso, a justiça deve ser perseguida, como melhor aliada na prática e na consecução do bem-comum (Dt 16,20; Sl 38,21), porque concretiza o šālôm bíblico (S1 34,15), e serve para afastar a possibilidade de maldição (Dt 30,7; Os 8,3).

posse é dada pelo Senhor, não haverá prosperidade se o povo abandonar a ordem recebida (WRIGHT, 2009).

${ }^{21}$ É uma forma típica e bem estratégica das línguas semitas, porque, quando deseja enfatizar, repete a mesma palavra (PAPOLA, 2011; PAGANINI, 2011).

${ }^{22} \mathrm{O}$ verbo dādap é facilmente compreendido, de forma concreta, quando o objeto, ou o alvo, é um inimigo (Gn 14,14-15; 31,23; Ex 14,4.8.9.23; 15,9; Dt 1,44; 11,4), uma caça (1Sm 26,20; Jó 13,25), mas também diz respeito à bebida inebriante buscada ininterruptamente durante o dia (Is 5,11). Contudo, "Um dos aspectos mais notáveis da providência divina é o fato de ele resgatar o seu povo da perseguição" (WHITE, 1998, p. 1403-1404). 
Então, de forma concomitante, estaria a ideia de nunca abandonar essa ação, mas que ela seja contínua, a fim de que, em momento algum da existência, o ser humano se afaste "do que é justo" ou "de quem é justo". Quanto mais convivência, mais adesão e assimilação do conteúdo a ser perseguido por quem foi colocado à frente do povo como juiz (Dt 1,16). A mesma ordem serve para as testemunhas ou para quem estiver implicado no processo e no julgamento, pois sem retidão não há justiça.

É, por isso, que o justo, quando lesado diante do ímpio e do malvado, clama e apela para justiça divina, na esperança de se ver livre das injustiças e dos seus perseguidores (S1 119,84.86.150.157.161). Assim, "quem pratica a justiça busca vida para si, mas quem persegue a maldade vai na direção da morte" $(\operatorname{Pr} 11,19)$. A razão para a justiça e a retidão está no Senhor que é a rocha firme da qual o povo, chamado a ser justo e reto, foi retirado e esculpido (Is 51,1). À ordem dada seguem duas fortes motivações e o seu fundamento.

\subsection{0 "para que vivas" (v. 20b)}

A primeira motivação está na direção diametralmente oposta à nefasta consequência da desobediência dos progenitores: a morte (Gn 2,17; 3,1-5). Segundo a narrativa bíblica, após a sentença de Deus teve início a "luta" pela vida e pela sobrevivência. É a história do ser humano que, para viver, deve aprender a obedecer a Deus, realizando a sua vontade ${ }^{23}$.

Essa é a lógica que se encontra na última ocorrência e clímax da decisão que é exigida em Dt 30,19 diante do céu e da terra, limites equidistantes, tomados como testemunhas, porque são canais da ação de Deus (OWENS, 2010). Moisés, assim, cumpriu a ordem que recebeu e, por isso, ficaria isento de qualquer culpa, caso as promessas não se cumprissem, não por "culpa" de Deus, mas porque o povo não obedeceu à ordem recebida.

Sem dúvida, o ser humano, em todos os sentidos, busca evitar a morte, mas percebe que a todo instante se encontra diante dela e cria, para si e para os demais, situações de morte. Por isso, o grande diferencial da Sagrada Escritura é a insistência na vida e na sua preservação.

23 O campo semântico do verbo hâyâ é muito amplo e abrangente: viver, possuir vida, estar vivo, permanecer vivo, cuidar da vida, sustentar a vida, voltar à vida, ter a vida restabelecida. A vida não está envolvida só do que é físico e material, mas, também, do mistério que dela toma conta, bem como da busca por tudo que a favorece (SMICK, 1998). O ser humano quer viver e não quer morrer. Contudo, não aceita viver uma existência penosa, marcada por dores, doenças e em constante luta contra a morte, ainda que se dê conta de que, a cada dia, está se orientando para a sua finitude natural (FERNANDES, 2019). Talvez, por isso, ao lado da árvore do conhecimento do bem e do mal, na narrativa bíblica, foi colocada a árvore da vida, como símbolo da fonte da vida e sinal de esperança da superação da morte. Não à toa, a teologia cristã ligou a árvore da vida à cruz de Jesus Cristo, mas, em particular, ao que jorrou do seu lado aberto: os sacramentos da salvação. 
Contudo, não basta viver, é preciso realizar todas as ações que possam ajudar a garantir a vida e a sua preservação. A primeira constatação é que a vida de uma pessoa depende da vida do seu semelhante, em particular do casal, mediante o qual cada espécie pode ser preservada. Esta é uma das principais razões para a narrativa do dilúvio insistir na salvação das espécies, fazendo entrar casais na arca, pois, além dos animais, Noé entrou com a sua esposa e seus filhos com suas respectivas esposas (Gn 6,17-22). Assim, assegurava-se que a criação não seria apenas preservada, mas, terminado o dilúvio, e de acordo com as promessas que foram feitas a Noé, os sobreviventes teriam, novamente, as condições naturais para se multiplicarem sob as bênçãos de Deus ( $\mathrm{Gn}$ 9,1).

A ordem dada (v. 20a) e sua primeira consequência devem ser unidas a um grande diferencial presente, exatamente, no livro de Deuteronômio: "Não só de pão viverá o ser humano, mas de toda palavra que sai da boca do Senhor" (Dt 8,3; S1 119,50.93). E a condição indispensável para que o povo eleito seja fecundo reside também no cumprimento de uma ordem: "Hoje, pois, eu te ordeno de amar o Senhor, teu Deus, de andar em seu caminho, de observar as suas ordens, os seus decretos e os seus juízos, e vivas e te multipliques, e o Senhor, teu Deus, te abençoe na terra que tu estás para entrar e tomar posse" (Dt 30,16) ${ }^{24}$.

\subsection{1 "e possuas a terra" (v. 20c)}

A garantia da vida e da existência está ligada ao alimento e este, por sua vez, depende de uma terra cultivável, boa e fértil. Não há como deixar de ver a ligação com a dupla promessa feita ao patriarca Abraão: descendência numerosa e terra habitável (Gn $15 ; 17)$.

Mais do que possuir a terra, o povo foi chamado a tomar posse, porque a terra não é sua, mas do Senhor. A terra é também um dom que deve, igualmente, ser por ele conquistado. Nesta dinâmica atesta-se um duplo movimento: do Senhor na direção do povo, através do dom, e do povo na direção de seu Deus pela correspondência aos seus planos (Dt 6,18; 12,29).

Então, de certa forma, "possuir a terra" é sinônimo de viver, pois se espera que na terra se encontrem as condições favoráveis à vida: água e campos cultiváveis. Sabe-se, porém, que a terra de Canaã não era a melhor terra da região, com grandes porções áridas que clamavam por transformação. Desse modo, o "novo Israel", que traz consigo a experiência do deserto, isto é, da terra seca, é chamado a manter, sobre este solo, a graça da identidade que recebeu como liberto: um povo consagrado ao Senhor que é o dono de toda a terra (Ex 19,5-6) ${ }^{25}$.

24 O ponto de partida de Dt 30,16 é o šema'(Dt 6,5), seguido da ordem de realizar o que é reto aos olhos do Senhor (Dt 6,19). Dt 4,1 e 32,47 emolduram essas ações.

25 A permanência do povo no deserto durante quarenta anos não provou apenas que $o$ Senhor cumpriu a sentença que decretou (Nm 14,20-38), mas, acima de tudo, demonstrou ser o Deus capaz de garantir a vida do seu povo onde, humanamente dizendo, nada sobrevive. Com isso, o Senhor provou que é justo e providente $(\mathrm{Sl} 78,19)$. 


\subsection{2 "que te dá o SENHOR, teu Deus" (v. 20d)}

Tanto os "juízes" como a "terra" são um dom do Senhor. Esta é a ênfase que recai sobre a ação. O cuidado é favorável à vida se existir reciprocidade entre os "juízes", os "oficiais", o povo e a terra. Por isso, sem a prática da justiça a terra não poderia ser ocupada e purificada de todos os erros que nela já haviam sido cometidos (BRUGGEMANN, 2001).

No fundo, Moisés procurou incutir no povo a verdade sobre a qual deveria edificar a sua vida na terra: para poder desfrutar de segurança e justiça, tinha que fazer de tudo para manter a ordem. Como o acampamento foi ordenado pelo Senhor, assim deverá ser na terra de Canaã.

Se existe liberalidade no sujeito que faz o dom, deve haver igual liberalidade em quem o recebe. Não se está, simplesmente, passando a terra das mãos do Senhor para as mãos do seu povo, mas é um ato de confiança depositado, razão pela qual o dom pode ser perdido caso haja negligência no que caracteriza a vida na terra de Canaã: a prática da justiça e do direito.

Nesse sentido, o dom da terra não é um prêmio por boa conduta do povo, mas um sinal da correspondência entre a decisão do Senhor e a obediência do povo. Na medida em que o povo responde com obediência ao seu Deus, a terra responde com a sua fertilidade, garantida pelo dom das chuvas no tempo oportuno ${ }^{26}$.

\section{Considerações finais}

À diferença do que ocorreu no Egito e durante o longo tirocínio vivido no deserto, o bem ou o mal que, na terra de Canaã, sobrevierem ao povo, dependerão, em primeiro lugar, das relações das pessoas com o Senhor, seu Deus, e, em segundo lugar, das relações entre elas pela administração da justiça e do direito: base do regime teocrático. A mensagem é direta e está pautada no que deve ser feito e no que deve ser evitado. Disso advirão as consequências (bênçãos ou maldições, conforme Dt 28).

Diante da experiência humana repleta de favoritismos, as três proibições, em si, podem causar um grande efeito se não forem esperadas apenas na vida dos que, na sociedade, têm a responsabilidade da administração da justiça e do direito. Essas ações proibidas devem ser respeitadas por todo o povo.

A esperança social não se baseia e não se constrói apenas com base numa política consensual e coercitiva, mas também depende do bom uso que cada cidadão aprende a fazer da liberdade. Por isso, não se cumpre a lei somente nos pontos que são convenientes.

26 Am 4,7 atesta que existe uma relação entre a condição espiritual do povo e o dom das chuvas. A base parece ser a teologia da retribuição. Quando o ser humano é correto e justo diante do Senhor, as chuvas são abundantes e suficientes (Dt 11,1017), pois o Senhor faz chover sobre a terra (Sl 147,8; Is 5,6) da mesma forma que fez o maná cair no deserto para alimentar os filhos de Israel (Ex 16,4; Sl 78,24). 
A lei de Deus e a sua justiça inspiraram muitas sociedades modernas, mas a igualdade tão sonhada continua esbarrando em diversos tipos de conflitos que ferem essa constituição e acabam por criar movimentos tirânicos. Os novos céus e a nova terra apenas poderão ser contemplados em uma sociedade que luta por vencer a corrupção, as fraudes e os subornos. Por isso, os que dizem acreditar em Deus e buscam professar a fé não podem se furtar aos apelos da justiça pautada na verdade que liberta e salva não somente de todas as formas de egoísmos e desigualdades, mas principalmente de seus nefastos agentes operadores do mal. Para todos, porém, o apelo à conversão é urgente, porque é eficaz na reorganização social.

Quando grandes porções de terra acabam nas mãos dos mais abastados que se tornam latifundiários, rapidamente o controle passa do que produzem ao domínio econômico do próprio país, assolando os mais pobres e necessitados dos bens mínimos para a sua vida e sobrevivência. Se a indignação toma conta do povo quando os juízes se tornam corruptos e permitem que os mais abastados levem vantagem sobre os menos favorecidos, cada um, igualmente, tem que se indignar consigo mesmo diante de suas pequenas corrupções.

O problema sobre o sentido da vida, para ser devidamente evidenciado pelo ser humano, precisa que antes seja reconhecido com base no próprio juízo que é capaz de emitir sobre si mesmo e sobre o uso que tem feito da sua liberdade. Assim, se aprende que viver é configurar a própria vida não a um qualquer modo de existir, mas a um objetivo que dá sentido e valor à existência: a promoção da justiça, que a todos impele e estimula a lutar pela própria vida na luta cotidiana pelo bem-comum.

\section{Referências}

AUSTEL, Herman. J. שִׁעַ (sha 'ar). In: HARRIS, Robert Laird; ARCHER JR., Gleason Leonard; WALTKE, Bruce K. Dicionário Internacional de Teologia do Antigo Testamento. São Paulo: Vida Nova, 1998. p. 1598-1600.

BALZARETTI, Claudio. Cronache. Milano: Cinisello Balsamo, 2013.

BARRETT, Rob. Religion and Politics in Deuteronomy and the Modern World. New York/London: T\&T Clark International, 2009.

BRUEGGMANN, Walter. Deuteronomy. Nashville: Abingdon Press, 2001.

CRIMELLA, Matteo. Luca. Introduzione, traduzione e commento. Cinisello Balsamo (Milano): San Paolo, 2015.

CULVER, Robert D. שִַָׁ (shāpaț). In: HARRIS, Robert Laird; ARCHER JR., Gleason Leonard; WALTKE, Bruce K. Dicionário Internacional de Teologia do Antigo Testamento. São Paulo: Vida Nova, 1998. p. 1602-1606.

FERNANDES, Leonardo Agostini. Análise do Salmo 110 e releituras no Novo Testamento. Caminhos, Goiânia, v. 13, n. 2, p. 270-288, jul./dez. 2015.

Os dons messiânicos em Isaías 11,1-3a. In: ROSSI, Luiz Alexandre Solano; SILVA, Valmor da. (Org.). Dons e carismas na Bíblia. São Paulo: Paulus, 2020. p. 37-56. 
Saúde e Espiritualidade. Rio de Janeiro: Editora PUC-Rio, 2019.

FERNANDES, Leonardo Agostini; GRENZER, Matthias. Exxodo 15,22-18,27. São Paulo: Paulinas, 2011.

FRESE, Daniel A. A Land of Gates: Covenant Communities in the Book of Deuteronomy. Vetus Testamentum, Leiden, v. 65, n. 1, p, 33-52, 2015.

FRIZZO, Antonio Carlos. Deuteronômio e Mishná: tradições que se unem na defesa dos pobres $\left(1^{\mathrm{a}}\right.$ parte). Atualidade Teológica, Rio de Janeiro, Ano 14, n. 36, p. 419-440, set./dez. 2010a.

Deuteronômio e Mishná: tradições que se unem na defesa dos pobres ( $2^{\mathrm{a}}$ parte). Atualidade Teológica, Rio de Janeiro, Ano 14, n. 36, p. 453-471, set./dez. 2010 b.

KOCH, Klaus. צדק. In: JENNI, Ernst; WESTERMANN, Claus. Diccionario Teológico Manual del Antiguo Testamento. Vol. II. Madrid: Cristiandad, 1978. p. 639-668.

LIEDKE, G. שפט. In: JENNI, Ernst; WESTERMANN, Claus. Diccionario Teológico Manual del Antiguo Testamento. Vol. II. Madrid: Cristiandad, 1978. p. 1252-1265.

LORENZIN, Tiziano. 1-2Cronache. Milano: Paoline, 2011.

MCCARTHY, Carmel. (Ed.). Bíblia Hebraica Quinta (quinta editione cum apparatu critico novis curis elaborato), אלה הדברים-Deuteronomy. Stuttgart: Deutsche Bibelgesellschaft, 2007.

MELLO, Alberto. Isaia. Introduzione, traduzione e commento. Torino: San Paolo, 2012.

OWENS, J. Edward. Deuteronomy. Collegeville (Minnesota): Liturgical Press, 2010.

PAGANINI, Simone. Deuteronomio. Milano: Paoline, 2011.

PAPOLA, Grazia. Deuteronomio. Milano: Cinisello Balsamo, 2011.

PATTERSON, Richard Duane. סָלָ (sālap). In: HARRIS, Robert Laird; ARCHER JR., Gleason Leonard; WALTKE, Bruce K. Dicionário Internacional de Teologia do Antigo Testamento. São Paulo: Vida Nova, 1998. p. 1047-1048.

. שטר (shōtēr). In: HARRIS, Robert Laird; ARCHER JR., Gleason Leonard; WALTKE, Bruce K. Dicionário Internacional de Teologia do Antigo Testamento. São Paulo: Vida Nova, 1998. p. $1550-1551$.

RICHARDSON, M. E. J. Hammurabi's Laws. Text, Translation and Glossary. London/New York: T\&T Clark International, 2004.

SMICK, Elmer, B. חָזיָ (hāyâ). In: HARRIS, Robert Laird; ARCHER JR., Gleason Leonard; WALTKE, Bruce K. Dicionário Internacional de Teologia do Antigo Testamento. São Paulo: Vida Nova, 1998. p. 454-458.

WALTKE, B. K. שָָׁר (shēbet). In: HARRIS, Robert Laird; ARCHER JR., Gleason Leonard; WALTKE, Bruce K. Dicionário Internacional de Teologia do Antigo Testamento. São Paulo: Vida Nova, 1998. p. 1511-1512.

WHITE, W. רִָָ (dādap). In: HARRIS, Robert Laird; ARCHER JR., Gleason Leonard; WALTKE, Bruce K. Dicionário Internacional de Teologia do Antigo Testamento. São Paulo: Vida Nova, 1998. p. 1403-1404. 
WILSON, M. R. נָָטָ (nātâ). In: HARRIS, Robert Laird; ARCHER JR., Gleason Leonard; WALTKE, Bruce K. Dicionário Internacional de Teologia do Antigo Testamento. São Paulo: Vida Nova, 1998. p. 956-958.

נָכָר (nākar). In: HARRIS, Robert Laird; ARCHER JR., Gleason Leonard; WALTKE, Bruce K. Dicionário Internacional de Teologia do Antigo Testamento. São Paulo: Vida Nova, 1998. p. 967-969.

WRIGHT, Cristopher J. H. Deuteronomio. Roma: Edizioni GBU, 2009. 